\title{
Conferring legal personality on the world's rivers: A brief intellectual assessment
}

\author{
Gabriel Eckstein \\ Ariella D'Andrea \\ ariella.dandrea@gmail.com \\ Virginia Marshall \\ virginia.marshall@anu.edu.au \\ Erin O'Donnell \\ erin.odonnell@unimelb.edu.au \\ Julia Talbot-Jones \\ julia.talbot-jones@anu.edu.au
}

Texas A\&M University School of Law, gabrieleckstein@law.tamu.edu

See next page for additional authors

Follow this and additional works at: https://scholarship.law.tamu.edu/facscholar

Part of the Environmental Law Commons, Natural Resources Law Commons, and the Water Law Commons

\section{Recommended Citation}

Gabriel Eckstein, Ariella D'Andrea, Virginia Marshall, Erin O'Donnell, Julia Talbot-Jones, Deborah Curran \& Katie O'Bryan, Conferring legal personality on the world's rivers: A brief intellectual assessment, 44 Water Int'l 1 (2019).

Available at: https://scholarship.law.tamu.edu/facscholar/1321

This Article is brought to you for free and open access by Texas A\&M Law Scholarship. It has been accepted for inclusion in Faculty Scholarship by an authorized administrator of Texas A\&M Law Scholarship. For more information, please contact aretteen@law.tamu.edu. 


\section{Authors}

Gabriel Eckstein, Ariella D'Andrea, Virginia Marshall, Erin O'Donnell, Julia Talbot-Jones, Deborah Curran, and Katie O'Bryan 
FORUM

\title{
Conferring legal personality on the world's rivers: A brief intellectual assessment
}

\author{
Gabriel Eckstein (D), Ariella D'Andrea, Virginia Marshall $\mathbb{D}^{\mathrm{D}}$, Erin O’Donnell $\mathbb{D}$, \\ Julia Talbot-Jones (D), Deborah Curran (ID) and Katie O'Bryan (D)
}

\section{Introduction to the series}

\section{Gabriel Eckstein}

Texas A\&M University School of Law; International Water Resources Association; International Association for Water Law

The following compilation is substantially reproduced and adapted from a series of essays that appeared in the blog of the International Water Law Project (www.inter nationalwaterlaw.org). The series was solicited in response to the unique recent phenomenon in which a number of courts and legislatures around the world have conferred legal personality on particular rivers. What resulted is a fantastic, thoughtprovoking and timely compilation.

In effect, various water bodies around the world have been accorded legal rights some though legislative actions and others via judicial decisions - that in some jurisdictions, equate with those recognized in human beings. Although there may be interesting parallels in rights accorded to corporations, children and the intellectually challenged, the practical implications of these particular actions are still not well recognized or understood.

Harkening back to Christopher Stone's remarkable 1972 article 'Should Trees Have Standing? Toward Legal Rights for Natural Objects', the series pursued some of the most fascinating and perplexing issues surrounding legal personality in rivers. What actual rights might such legal personality provide? How does a river represent itself in court and before other societal institutions? If a river can suffer harm and sue alleged perpetrators of that harm, might it be subject to lawsuits for damages it might inflict as a result of flooding? What resources might a river have at its disposal to protect its rights? Does the recognition of such rights comport with the rights, interests and perspective of indigenous peoples? These are just some of the unique issues considered in these provocative essays.

The legislative and judicial actions discussed in this series are a novel legal approach to the management of critical freshwater resources. These mechanisms, however, have yet to be fully evaluated, scrutinized and tested. The essays that follow constitute a thought-provoking effort to contribute to that assessment. Moreover, they were written 
with the sincere objective of ensuring the sustainability of unique freshwater resources around the world.

The International Water Law Project is itself a unique institution. Existing solely on the Internet, the website is one of the premier resources and clearinghouses for information on international water law and policy. Its purpose is to educate and provide relevant resources to researchers and the public and to facilitate cooperation over the world's freshwater resources.

\section{Can the river spirit be a person in the eye of the law?}

\section{Ariella D'Andrea}

Coastal Fisheries and Aquaculture Legal Adviser, Pacific Community-SPC; International Association for Water Law

In the last decade, the environment and a number of water bodies have been granted rights and legal personality either through legislation or through court decisions. The personification of nature is not new. Humans have long considered their environment or some of its main components - the sun, the moon, the earth, the ocean, the rain, the river, the lake - as living entities or even gods. These beings, however, were outside or above the law. Now that our environment is deterioriating despite all the laws and treaties adopted to protect it, we feel that we ought to defend its existence, not just for our sake but also for its own survival. Just as oppressed minorities throughout history have become right-holders to defend their identity, nature is now being granted rights of its own. It is becoming a legal person like corporations, public agencies or civil associations.

\section{Formalizing the rights of nature through legislation}

In the United States, municipal ordinances recognizing the right of nature to exist, thrive and evolve have been adopted since 2006 in several states through grass-roots initiatives spearheaded by the Community Environmental Legal Defense Fund. Rights are conferred on 'natural communities and ecosystems', including the right to water, and residents are established as legal representatives to enforce nature's rights, as found, for example, in sections 618.03(a) and (b) of the Pittsburgh anti-fracking ordinance adopted in 2010 (City of Pittsburgh Code of Ordinances, 2019).

Latin America was next to adopt legislation on the rights of nature. In 2008, Ecuador recognized the constitutional right of Mother Earth to exist and evolve (Constitution of the Republic of Ecuador, 2008, Section 71), which was successfully tested in the Provincial Court of Justice of Loja in 2011 for the protection of the Vilcabamba River (R.F. Wheeler \& E.G. Huddle v. Attorney General of the State of Jola, Dr. P. Carrion, 2011). In 2010, Bolivia adopted Law No. 071 on the Rights of Mother Earth, which gives legal standing to nature by recognizing it as a legal person of public interest ('sujeto colectivo de interés público', Art. 5) and establishes an ombudsman for the protection of its rights (Defensoría de la Madre Tierra, Art. 10) (Bolivia, 2010). The guiding principles of environmental governance are further specified in Framework Law No. 300 of Mother Earth and Integral Development for Living Well 2012 (Bolivia, 2012). Both 
countries recognize the right of nature to the protection of its waters (Bolivia, 2010, Art. 7(I)(3); Ecuador, 2014, Art. 64).

More recently, New Zealand adopted national-level legislation granting legal personality to specific areas of cultural and environmental significance: Te Urewera, comprising Lake Waikaremoana and surrounding land and forests, as can be inferred from the Te Urewera Act (New Zealand, 2014); and Te Awa Tupua, which encompasses 'the Whanganui River from the mountains to the sea, incorporating all its physical and metaphysical elements' (New Zealand, 2017, Section 12). The new legal entities are represented by the Te Urewera Board and two guardians known as Te Pou Tupua, respectively. Both acts implement the deeds of settlement of historical claims by the Mãori people.

\section{Formalizing the rights of nature through judicial process}

A number of courts around the world have also taken steps to recognize the rights of nature in the absence of enabling legislation. In 2016, the Constitutional Court of Colombia recognized the Atrato River as a legal person ('entidad sujeto de derechos') to be legally represented by a commission of guardians (T-622/16, 2016). In 2017, the High Court of Uttarakhand, India, declared the Ganga and Yamuna Rivers and all their tributaries legal persons and appointed two legal representatives in loco parentis (Mohd. Salim v. State of Uttarakhand \& others, 2017). A few days later, the same court declared 'the Glaciers including Gangotri \& Yamunotri, rivers, streams, rivulets, lakes, air, meadows, dales, jungles, forests, wetlands, grasslands, springs and waterfalls' in the State of Uttarakhand legal persons and appointed four legal representatives in loco parentis (Lalit Miglani v. State of Uttarakhand \& others, 2017). In July 2017, the Supreme Court of India stayed the operation of the first order based on a petition by the State of Uttarakhand reporting a number of legal and administrative issues, e.g., a single state cannot be responsible for a river that flows beyond its borders (Mandhani, 2017; State of Uttarakhand \& Ors. v. Mohd. Salim \& Ors., 2017).

Most recently, in September 2017, the Colorado River Ecosystem/Deep Green Resistance et al. v. State of Colorado case was filed in the Federal District Court for the recognition of personhood of the Colorado River. It was withdrawn by the plaintiff following serious threats of sanctions from the Colorado Attorney General's Office on the grounds that the case is unlawful and frivolous (Walker, 2017).

\section{Future opportunities}

Other countries are also exploring the possibility of granting rights and legal personality to certain components of their environment. Canada is looking into granting legal personality to Lake Winnipeg (Walker, 2014) and Australia has now recognized the Yarra River (Victoria) as 'one living and integrated natural entity' although not (yet?) as a legal person (Yarra River Protection (Wilip-gin Birrarung murron) Act, 2017). A Universal Declaration on the Rights of Mother Earth - which includes the right to water - was also proclaimed by a number of countries at the World People's Conference on Climate Change and the Rights of Mother Earth (2010) in Cochabamba, Bolivia, in 2010. 


\section{Critical questions remain}

The debate on whether nature should have legal standing has been ongoing at least since 1972 (see the dissenting opinion of US Justice William O. Douglas in Sierra Club v. Morton, 1972), but many questions remain open. The diversity of approaches adopted in different countries does not help in bringing clarity to the topic. Is granting rights to rivers a case of codification of customary law or practices? Are we moving from an anthropocentric viewpoint to an eco-centric one, or are nature's rights only a way to ensure that our biosphere remains inhabitable for future human generations?

Further questions include: Who or what is being granted legal personality: the river, the river basin, the freshwater ecosystem, or the environment as a whole? Does the single fish or weed in the water have legal standing, or are we protecting aquatic biodiversity? What about the riverbanks and the surrounding trees and bushes? Humans are also undoubtedly part of the ecosystem as generally recognized. Does this mean that sustainable use is acceptable as long as the functioning of an ecosystem is maintained (relations between its components), or do we need to protect the integrity of the natural object (the river) or process (the ecosystem)?

If nature has a bundle of substantive and procedural rights (to exist, thrive and evolve; to have water; to sue and be sued; to enter into contracts; to hold property; to be compensated for damages; and so on), doesn't it have duties too (to pay taxes, to be liable for damages such as floods, to maintain water quality and quantity)? What is the difference between a national park or protected area managed by a special-purpose body and a natural area declared to be a legal person? Does the ownership of the natural object or of the land where it lies have to be transferred to the new legal person (as in the Whanganui River Act) or does the state retain ownership (as in the South American examples)? What type of law applies to the relations involving the new legal person: public (constitutional, administrative, criminal) or private law? Would it be meaningful to introduce the crime of ecocide?

Most importantly, the new legal person needs to be made operational by clearly setting its defining features. What type of body is it? Is it a public authority, a charity, a body corporate? Or is it treated differently under different laws (e.g., Whanganui River Act, Section 17)? What are its exact scope and mandate? Are its boundaries clearly delimitated? What are the powers of its legal representatives or guardians? Who are its members? How do we make sure that decisions are made in the best interest of nature itself or of a given ecosystem? Is there a dissolution procedure? Finally, if a transboundary water body is granted legal personality, the repercussions on the right of states to regulate the flow of international rivers will need to be explored.

\section{Overturning aqua nullius: an aboriginal perspective on personhood}

\section{Virginia Marshall}

School of Regulation and Global Governance and Fenner School of Environment and Society, Australian National University

The proposed push by some individuals and groups to apply legal personhood to rivers, and potentially extend this to other living things, is counterintuitive from an Aboriginal perspective, and essentially counterproductive. 
Australia is in Western terms a nation-state. If we measure Australia's short history against the thousands of years of Indigenous heritage, bound as it is by birthright in a familial connection and relationship with everything on, above and below the land and waters since time immemorial, the latter far outweighs any value flowing from propositions of legal personhood.

Water landscapes hold meaning and purpose under Aboriginal laws. The inherent relationships of Aboriginal peoples with water are evidenced by Aboriginal creation stories, with Aboriginal identity defined through Aboriginal ontologies (Aboriginal normative values and beliefs, laws and knowledge). From an Aboriginal perspective, water is inseparable from the land; in many Aboriginal creation stories (not myths) water came first, then the land. Water is sacred and underpins Aboriginal kinship connection in birth, life and death. These traits are exemplified in Aboriginal obligations to maintain waterholes, ensure fire management (burning) practices, and monitor the health of all things within traditional boundaries and care for country. Aboriginal communities continue to seek to exercise their inherent rights and obligations as sovereign peoples, in spite of continual efforts in contemporary Australia to undermine Aboriginal property relationships, ownership of resources and ancient knowledge.

\section{Why do aboriginal peoples continue to fight for rights to protect country?}

In Mabo v. Queensland (No. 2) (1992), a majority of Australia's High Court determined that the doctrine of terra nullius (in simple terms, land belonging to no one) was not based on truth; that Aboriginal peoples did have settled laws, were sovereign, and had exercised continuing ancient traditions, customs and practices. In 2004, when Australia's federal government legally separated water from the land, creating a market-based water regime, Indigenous peoples were not consulted. Aboriginal communities, throughout over 200 years of colonization, have been invisible in colonial constitutions and federalism (federation of Australia's colonial states occurred in 1901). Australia's Constitution affirms the invisibility of the First Peoples. Social activism (people's movements) still run cold on restoring Aboriginal peoples' leadership role on land, water and resource management. My book, Overturning Aqua Nullius (Marshall, 2017), conceptualizes the ongoing challenges as the various stakeholders, vested interests and governments in Australia continue to regard Indigenous First Peoples in Australia as merely another stakeholder or a 'special interest group' - a minority group.

The First Peoples of Australia have experienced waves of Western policies and laws to remove, alienate and assimilate communities and individuals, and this Western legal construct is complicit in decoupling the oldest living and continuing Indigenous culture in the world.

\section{Why is the proposed UN declaration of the rights of Mother Earth misguided?}

The proposed declaration fails to identify the unique position of Indigenous peoples, for example within the gendered environment of land, water and living things, which informs and connects Aboriginal identity (freshwater peoples, saltwater peoples, etc.) in 'a web of relationships' balance. The assumption in the 'rights of nature' paradigm is that all 'beings' seek to 'exploit, destroy and abuse' the earth. The concept of Mother 
Earth is described as hierarchical in the order of all things (Art. 1), above 'beings'; separating 'each being' in 'relationships' with the Mother Earth.

The preamble, which refers to 'recognition and to defend the rights of Mother Earth' appears oppositional to the inherent role of Aboriginal peoples to manage and protect their country, including the lands, the waters, and totemic relationships with plants and animals. The preamble uses language that imposes restrictions on Aboriginal laws, limiting and regulating inherent Indigenous rights and obligations (Art. 1(7)). Notably, Article 3 presupposes that Aboriginal communities' values, beliefs, customs and laws are not adequate to maintain obligations to care for country. Article 3(e) seeks 'effective norms and laws' to defend the earth, effectively dismissing existing Aboriginal norms, laws and practices. It has been stated that 'a new generation of lawyers are searching for ways to transform the legal systems of industrialised nations to nurture a harmonious relationship between people and the non-human world' (Australian Earth Laws Alliance, n.d.), for example through legal personhood theory. This proposition is antithetical to Aboriginal peoples' inherent rights and obligations as First Peoples, which have operated effectively for tens of thousands of years in Australia.

\section{Should we be persuaded by Salim v. State of Uttarakh and High Court decision?}

A reading of the judgement of Sharma J. (and Alok Singh J.) in mandatory directions to the central government and state governments (Uttar Pradesh and Uttarakhand) to cooperate to 'preserve and conserve the Ganga and Yamuna rivers' makes certain things clear. This is an unusual role for the courts, in view of Australia's separation of powers. Sharma J. refers to a decision whereby the Indian Supreme Court held that a Hindu idol was a juristic entity (of legal personality) capable of holding property and of being taxed under a trust arrangement, and that this entity must have human guardians (Yogendra Nath Naskar v. Commission of Income-Tax, 1969). Juristic persons were said to be developed due to human need, as in the construction of corporate entities, with rights and duties, to sue or be sued (Shriomani Gurudwara Prabandhak v. Shri Som Nath Dass \& Ors., 2000). The High Court's order to give legal status (to be read with Arts. $48 \mathrm{~A}$ and $51 \mathrm{~A}(\mathrm{~g})$ on 'protection of the environment' in the Constitution of India) accords the significance of the Ganga and Yamuna Rivers to all Hindus, and the continued supply of water to industry, communities, power generation and navigation (Mohd. Salim v. State of Uttarakhand \& others, 2017).

The concept of a legal entity is not of itself trailblazing territory. In relation to introducing and advocating for the legal personality of a river, advocating for the rights of nature on the grounds that all humans over-exploit, abuse and contaminate the environment is misleading. The Indigenous peoples of Australia have a primary, unique and inherent obligation to exercise the ownership, protection and management of the Australian environment, but Australian domestic laws and policies do not fully support Indigenous Australians in the exercise of such obligations. For example, in Australia's blueprint for water resource use, the National Water Initiative, Indigenous peoples do not have legal certainty and only three discretionary clauses $(52,53$ and 54) to represent thousands of years of actively maintaining pristine waters, lands and respect for all living things (Council of Australian Governments, 2004). Indigenous peoples in Australia have been, and continue to be, impacted by the untruths of the doctrine of discovery - terra nullius and aqua nullius - and they continue to be invisible to those 
seeking to exercise proprietary rights over Australia's rivers. For decades, Aboriginal people have struggled for land rights and native title, for truth and reconciliation and for constitutional recognition. We are not willing to see the door shut in our face when it comes to our rights and obligations to our rivers.

\section{When a river becomes a person: polarizing environmental protection}

\section{Erin O'Donnell}

\section{Melbourne Law School, University of Melbourne}

In 2017, mainstream environmental law experienced a seismic shift. Over 40 years after Christopher Stone's (1972) provocative article, and seven years after the most recent experiments in giving nature legal rights in Ecuador and Bolivia, courts and legislatures around the world began to recognize rivers and other natural objects as legal persons (O'Donnell \& Talbot-Jones, 2017a). The impact of these radical legal reforms should not be overstated: Stone's original concept was the subject of open mockery (in verse, no less; see Burdon, 2010), and despite ongoing grass-roots campaigns run tirelessly by environmental NGOs, prior to 2017, the concept of legal rights for nature remained well outside the legal mainstream. Since March 2017, legal rights have been extended to forests, glaciers, animals, mountains, and of course more rivers, and are now considered integral for future environmental law reform, even in countries such as Australia, where legal rights for nature have not been formally created (Australian Panel of Experts on Environmental Law, 2017).

But in all the excitement, there is emerging evidence that granting legal rights and legal personality to rivers can actually lead to people being less willing to protect those rivers (O'Donnell, 2018). This outcome can undermine the potential benefits of granting rights to rivers in the first place.

\section{What does it mean when a river is a person?}

Rivers have been recognized as legal persons, which are not the same as human persons. A legal person is the recognition of a specific entity as being capable of bearing rights and duties in law, and although it is a profound statement about who matters to the law, it does not necessarily confer any moral worth (Naffine, 2009).

Moreover, legal rights are not the same as human rights. Legal personhood typically confers three specific rights:

- the right to enter into and enforce contracts;

- the right to own and deal with property; and

- the right to sue (and be sued) in court, commonly referred to as legal standing (O’Donnell \& Talbot-Jones, 2017a).

Other rights may be conferred in specific circumstances, including the right to exist. Legal standing is typically seen as the most important new legal right, as it enables the river to take legal action to protect itself, without having to demonstrate harm to human users of the river (O’Donnell \& Talbot-Jones, 2018). 


\section{Why would a river need rights?}

Granting legal rights to rivers is frequently portrayed as a clear victory for environmental protection. However, the evidence indicates that there are at least four specific reasons for giving rivers rights:

- to give effect to First Nations' laws, values and relationship to country, particularly in colonial contexts;

- to elevate the river to equal status in the law with human beings (eco-centrism);

- to enable the river to participate in water and ecosystem services markets (market environmentalism); and

- to enable the river to advocate for its own interests in policy debates (private interest regulatory theory).

Table 1 compares three jurisdictions in which rivers have received legal rights, as well as the environmental water managers of Australia and the United States (which extend legal rights to rivers by proxy, as a combination of their legal form and function; see O’Donnell, 2017). In all cases, multiple reasons have been used to justify granting legal personality to rivers.

But these varied reasons can be uncomfortable bedfellows. Eco-centrism recognizes that we are all part of the one system, emphasizing the collective good, whereas market environmentalism emphasizes private property rights and commoditizes nature. First Nations' values will not always align with environmental protection.

Most fundamentally, all these rivers have been given legal rights and legal personality to enable them (via their guardians or other responsible organization) to have a 'voice' in policy debates. This presupposes that the creation of public policy and regulation requires all interested parties to participate in that process, and that the eventual regulation is merely the outcome of multiple, competing voices (Morgan \& Yeung, 2007). Giving rivers a voice takes the focus away from the collective good and the need for policy makers to specifically protect the vulnerable (Sunstein, 1990), and shifts responsibility for their own protection to the rivers themselves.

This shift in responsibility has two important corollaries. First, to adequately protect its own interests, a river's voice must be powerful enough to be heard (Croley, 1998).

Table 1. Reasons for giving rivers legal personality and legal rights.

\begin{tabular}{|c|c|c|c|c|}
\hline Reasons for rights & $\begin{array}{c}\text { Aotearoa New } \\
\text { Zealand } \\
\text { Whanganui River }\end{array}$ & $\begin{array}{l}\text { Colombia } \\
\text { Río } \\
\text { Atrato }\end{array}$ & $\begin{array}{l}\text { Uttarakhand (India) } \\
\text { Ganges and Yamuna } \\
\text { Rivers; all of nature }\end{array}$ & $\begin{array}{c}\text { Environmental water } \\
\text { managers (US and } \\
\text { Australia) }\end{array}$ \\
\hline First Nations laws & $x$ & $\mathrm{x}$ & $\begin{array}{c}\text { Partial } \\
\text { (Hindu religion) }\end{array}$ & \\
\hline Eco-centrism & & $\mathrm{x}$ & $\mathrm{x}$ & $\begin{array}{c}\text { Partial } \\
\text { (not explicitly eco- } \\
\text { centric) }\end{array}$ \\
\hline Market environmentalism & & & & $\mathrm{x}$ \\
\hline $\begin{array}{l}\text { Private interest regulatory } \\
\text { theory }\end{array}$ & $\mathrm{X}$ & $\mathrm{X}$ & $\mathrm{X}$ & $x$ \\
\hline
\end{tabular}


This requires a guardian with sufficient funding, organizational identity, and independence from government.

Second, a river must promote its own interests ahead of those who rely on the river, which emphasizes conflict and competition. Relying on the river to protect itself not only enables us to be complacent, it also entrenches humanity in an adversarial relationship with the environment.

\section{River rights can polarize communities (but they don't have to)}

On 26 February 2019, citizens of the Ohio city of Toledo voted to approve a proposal to give Lake Erie legal rights (Javorsky, 2019). The campaign, run by the community group Toledoans for Safe Water, emphasized the importance of the lake in providing safe water supplies. In the summer of 2014, Lake Erie had experienced an extreme pollution event, which cut off drinking water supply for the city for three days. Despite this very recent reminder that environmental health underpins the city's access to safe, secure water supplies, the measure has polarized the community. Farmers acknowledge that most of the pollution is caused by agricultural runoff, but (understandably) saw the proposal as an attempt to give environmental NGOs the means to sue them on the lake's behalf (Williams, 2019). Rather than building a consensus around the need for clean water, legal rights for the lake may make it harder to address polluting activities.

However, this kind of conflict is not a foregone conclusion. River rights in Colombia and Aotearoa New Zealand have been the focus of renewed collaboration between multiple stakeholders, and in Australia, environmental water managers are enhancing their legitimacy with a broad cross-section of the community, even as the MurrayDarling Basin conflicts intensify (O’Donnell \& MacPherson, 2018). Early lessons from these experiences include:

- Building and maintaining community support for why rivers need protecting, and the benefits of healthy rivers to all of us;

- Centring First Nations' perspectives and values, which encompass millennia of learning how to live sustainably with rivers; and

- If we do expect rivers to compete for outcomes, ensuring they have adequate funding and organizational support.

\section{Flowing from fiction to fact: the challenges of implementing legal rights for rivers}

\section{Julia Talbot-Jones}

Victoria University of Wellington

Granting a river legal standing may sound like the stuff of fiction, but in 2017 four rivers were granted legal rights in rapid succession: the Whanganui River in New Zealand (Roy, 2017), the Ganges and Yamuna Rivers in India (Chandran, 2017), and the Rio Atrato in Colombia (Mount, 2017). Although these recent events washed away the fictional narrative, questions remain about how the approach will work in practice. 
This essay engages with the practicalities of effective governance, drawing comparisons between the Whanganui River case and the India examples to understand the circumstances under which the approach may be a useful governance tool. It will also shine light on some of the social costs of granting rivers legal rights that may be otherwise unanticipated by policy makers.

\section{What determines the effectiveness of legal rights for rivers?}

The effectiveness of using the granting of legal rights to rivers as an alternative water governance approach is likely to depend on how the change is enacted and the broader framework in which it is embedded.

In the case of the Whanganui River, eight years were taken to develop an institutional framework that incorporated the Mãori worldview into legislation in a way that could work with existing laws and social norms (Salmond, 2014). Granting the Whanganui River and its catchment legal rights through legislation was a pragmatic way of achieving this (Radio New Zealand, 2017).

Motivation for the change came from needing to resolve ownership issues, which had been long-standing and costly for Whanganui Iwi (the local Māori tribe) and the Crown (New Zealand government), as well as other river users (Waitangi Tribunal Report, 1999). As a result, in designing the new framework the actors involved (the Iwi and the Crown) were economically and socially invested in reaching a successful resolution. Further, those involved in designing the institutional arrangement were those most likely to be affected by the changes. This gave the actors a feeling of ownership over the end result and allowed local knowledge to be incorporated into the decision-making process and legislation.

The resulting institutional framework, Te Pā Auroa nā Te Awa Tupua (New Zealand, 2017, Part 2), also includes rules designed to control some of the more obvious risks and costs of granting rivers legal rights, such as rent-seeking by the guardians and processes for managing conflict over competing uses. It defines a boundary around the affected area (the catchment) and specifies who retains what responsibilities over decision making. Further, the new framework was designed to be implemented in two stages to smooth the transition and provide the opportunity for adaptation, as needed.

In contrast, the Uttarakhand court in northern India instated legal rights for the Ganges and Yamuna Rivers in a surprise ruling (Mohd. Salim v. State of Uttarakhand \& others, 2017) two days after the Whanganui River legislation was announced. The designation of legal rights was designed to trigger a substantive shift in how the rivers were managed and protected in law, but there seems to have been little thought to how the change would work in practice.

For instance, the Ganges and Yamuna Rivers are transboundary rivers that stretch across several states in India, as well as into Bangladesh. This means that a state ruling from northern India may struggle to be enforced in other jurisdictions. Further, the absence of an integrated institutional framework means that there is little guidance for the guardians on how they are supposed to behave or where the limits of discretion lie. The conflation of legal person and living person in the court decision complicates this further by failing to properly define (or codify) the rights' breadth (O’Donnell \& Talbot-Jones, 2018). 


\section{Unintended consequences of granting legal rights to rivers}

For policy makers or judicial experts interested in granting rights to rivers, the elements of the broader Te Awa Tupua framework are important to note, particularly because, in the absence of an integrated framework, granting a river legal rights could have unintended consequences for society as a whole.

For example, recognizing a river as a person will require the political system to find ways and means to deliver and uphold a river's new legal rights, sometimes at the direction of the courts. Because judges do not typically have the discretion to make decisions based on the potential consequences of their decrees, this means that upholding the rights of the river may impose unexpected costs on other sections or scales of society.

Further, although granting legal rights to rivers has the potential to benefit some industries and professionals, who stand to gain by providing court-mandated goods and services, it also carries the risk of forcing the court to become politicized. This could compromise moral authority and public confidence in the system. The series of events following the Uttarakhand decision provides evidence of how this can, and has, occurred (BBC News Service, 2017).

Granting legal rights to rivers also places the responsibility of looking after, and representing, the environmental good or resource in the appointed guardians, rather than elected officials. Without broader institutional and financial support, this means that only wealthy or well-endowed representatives will be able to challenge decisions and enter costly litigation, should a river wish to sue or find itself the subject of an individual or class action.

Given the financial burden of engaging in judicial process, perhaps it is not surprising that Ecuador - a country that granted all of nature legal rights in 2008 (Constitution of the Republic of Ecuador, 2008; Revkin, 2008) - has had only three cases of the rights of nature being successfully brought to court by civil society (Kauffman \& Martin, 2017). In the first case, two American residents who live parttime in Ecuador brought a case against the provincial government of Loja on behalf of the Vilcabamba River. The plaintiffs owned property downstream of a road that was to be widened and that runs past the river. The couple argued on behalf of nature that the new construction was adding debris to the river and thus increasing the likelihood of floods that affected the riverside populations that use the river's resources (Daly, 2012).

Admittedly, in the case of the rivers discussed here, nominated guardians have been appointed to speak on behalf of the rivers, and in the case of the Whanganui River, a NZ\$ 30 million contestable fund has been created for the purposes of improving $\mathrm{Te}$ Awa Tupua's health and well-being, as well as litigation purposes. However, in the case of the Ganges and Yamuna Rivers, no financial support has been provided, which limits the legitimacy and power of their legal rights, and that of the guardians who represent them.

\section{Conclusions}

Overall, granting the Whanganui River and its catchment legal rights set a new precedent for water governance globally. It was one of the most significant changes in 
water management in the past decade and demonstrates that granting rights to rivers is now more fact than fiction.

However, comparing the case of the Whanganui River with the examples of the Ganges and Yamuna also draws attention to the fact that the reason why granting legal rights to rivers may be an effective water governance tool is because the broader institutional framework embeds the new system into existing legislative structures.

For policy makers interested in using legal rights as an approach to the governance of rivers, considerations of institutional design and the potential effects on wider societal outcomes are important to note. With any luck this will reduce the risk of additional costs arising when rivers are granted legal standing in the future.

\section{Independent legal personhood of rivers or relational stewardship? A perspective from $\mathbf{2 0 \%}$ of the world's freshwater (Canada) and the Indigenous-colonial legal tensions that govern it}

\section{Deborah Curran}

Faculty of Law and School of Environmental Studies and Environmental Law Centre, University of Victoria

In Canada, the country with $20 \%$ of the world's freshwater, our colonial legal history and the current expression of both colonial and Indigenous laws make for a unique context that does not necessarily lend itself to the application of independent legal status or personhood for natural features such as rivers and mountains. While amendments to colonial law could grant legal status to rivers, many Indigenous legal orders place Indigenous peoples in a stewardship or caretaking relationship with water that they view as fundamental to their laws and culture. Devolving authority to an independent representative or tribunal and separating Indigenous people from direct responsibility for their environment is viewed as harmful to both people and ecosystem. Indigenous communities are responsible for maintaining relationships as part of their legal and cultural duties. Creating a third-party structure, even with representation, may not adequately adhere to Indigenous law. In addition, once communities agree to devolve decision-making authority to a third-party representative of a river, there is always the danger that the Crown - federal and provincial governments - may take the position that Indigenous communities then have less say in proposed development and impacts on the river. How independent structures representing a river could limit or change evolving Aboriginal rights and title is a significant risk for Indigenous communities.

There is considerable energy going into revitalizing and expressing Indigenous laws in Canada, including entering into government-to-government agreements that amend colonial law. These acts of Indigenous law could result in protections for the natural environment and specific features such as rivers that are similar to those promised by granting independent legal status to rivers and the natural environment. At least in the medium term, the focus in Canada is on revitalizing Indigenous laws to be an effective 
articulation of Indigenous authority and counterpoint to colonial environmental governance.

\section{Environmental protection and Aboriginal rights and title in context}

There is no right to a healthy environment in Canada under current state or colonial law (Boyd, 2012). The environment, except for fish, is largely the responsibility of provincial and territorial governments, which have created a patchwork of different laws regulating the extraction of natural resources, parks and pollution. All water law in Canada focuses on permitting the extraction of water rather than planning for watershed health, and none acknowledges Aboriginal rights to water as part of the water balance in a region.

Since 1982, the federal Constitution Act affirms and acknowledges Aboriginal and treaty rights. Colonial courts have interpreted the scope of these rights to include the right to harvest for food, social and ceremonial purposes and carry out cultural practices in one's historic territory (R. E. Sparrow v. The National Indian Brotherhood/Assembly of First Nations et al., 1990). Beyond this bare right to harvest for a moderate livelihood and undertake activities that are 'distinctive to the culture' of an Indigenous community (R. v. Van der Peet v. The Attorney General of Quebec et al., 1996), most court cases exploring Aboriginal rights focus on the Crown's requirement to consult and accommodate First Nations when the provincial or federal governments make decisions about applications to use resources in the traditional territory of an Indigenous community (Haida Nation v. British Columbia (Minister of Forests), 2004). This duty is a procedural right and does not a guarantee a substantive outcome of a healthy environment, intact ecological relationships, or the ability to exercise one's Indigenous laws.

Recently, however, First Nations and colonial courts have turned to Indigenous laws and Aboriginal rights, as well as their expression in government-to-government agreements, as legitimate limitations on the decision-making authority of the federal and provincial governments, and as a way to challenge the natural resource regimes, including for water, under colonial law.

\section{Indigenous law}

As a multi-juridical society, there is a resurgence in the expression of Indigenous law in Canada, the foundation of which are the relationships and responsibilities between land, plants, animals, fish, marine ecosystems and humans. Colonial law stands in contrast to Indigenous law, which encompasses the existing and evolving laws of each Indigenous society. Indigenous groups and communities in Canada continue to define and use their own laws. The land- and water-based origin of many Indigenous laws establish relationships and rules for protection, harvesting, cultivation and trade of ecosystem elements. The origins of Indigenous laws flowing from ecosystem-based relationships also create the overarching governance processes through which entitlements to use, harvesting practices and sharing with adjacent communities are mediated (Napoleon \& Overstall, 2007).

The Tsleil-Waututh Nation conducted their own environmental assessment of the Trans Mountain Pipeline expansion proposal using their stewardship policy, derived from their Indigenous laws, as the assessment framework (Tsleil-Waututh Nation, 
2015). Tsleil-Waututh and Coast Salish legal principles include the 'sacred obligation to protect, defend, and steward the water, land, air, and resources of our territory ... the responsibility to maintain and restore conditions in our territory that provide the environmental, cultural, spiritual, and economic foundation our nation requires to thrive'. The stewardship policy requires the Nation to evaluate the potential negative effects of proposed development, and if those effects do not exceed 'Tsleil-Waututh legal limits', to assess the benefits of the project for the community. As part of the assessment process, the Tsleil-Waututh First Nation revealed their stewardship obligations in their territory, based on their Indigenous laws and operationalized through their Burrard Inlet Action Plan, which includes regulatory action and habitat restoration by the Tsleil-Waututh (Tsleil-Waututh Nation, n.d.).

Likewise, the Stk'emlúpsemc te Secwépemc Nation (2017) undertook a community assessment of the proposed Ajax mine near Kamloops, British Columbia. Concluding that the Nation would not give its free, prior and informed consent to the project, the process included the Nation exercising its own Indigenous environmental governance to strike an assessment panel. The decision document underscores the importance of the ethics of stewardship embedded in socio-ecological relationships and expressed in Secwépemc lands and resource laws (Asch, Broadhead, Lloyd-Smith, \& Owen, 2018).

Other examples of expressions of Indigenous laws that challenge colonial administrative and legal processes abound in Canada, particularly on the west coast, in British Columbia. Many of these expressions involve water as the basis of life. The Nadleh Wut'en and Stellat'en First Nations (Carrier Sekani Tribal Council, n.d.), as well as the Okanagan Nation Alliance (n.d.), have made declarations of water law and are developing programmes and policies flowing from these declarations. A central tenet of these expressions of law is the relationship of these communities to their lands and waters, and their ongoing responsibility to take care of the ecosystem's health.

\section{Cautionary approach to legal personhood}

Currently in Canada, there is a movement to revitalize Indigenous laws and to enable those laws to express jurisdiction and sovereignty and interact with colonial law as one of the long-term results of reconciliation. Permitting the full expression of Indigenous laws may mean granting legal status to some rivers as part of government-to-government agreements, but such an approach would follow first the concrete expression of Indigenous legal orders and long-term discussions about the appropriate ways to enliven those orders in conversation with colonial law.

A legitimate concern is that colonial legal processes or governments could weaken the intent of legal status for rivers vis-à-vis evolving claims to Aboriginal rights and title. While Indigenous communities would sign on to such an approach as a way to secure better protection for the natural environment, and thus the underlying conditions of their Aboriginal rights such as fishing, hunting, gathering and ceremonial practices, the Crown may argue that First Nations' interest in applications for development or extraction of natural resources is diminished because the river had independent representation. Indigenous influence on potential projects could be limited to direct impacts to Indigenous people and not the environmental health of the river as an ancestor, spiritual entity or condition of life. 
There may be opportunities in the medium-to-long term where expression of Indigenous laws include government-to-government agreements that point to legal personhood, as in New Zealand. Several productive government-to-government agreements exist in Canada. For example, the Haida Nation entered into the 2009 Kunst'aa guu-Kunst'aayaa Reconciliation Protocol (2009) with the Province of British Columbia to create the Haida Gwaii Management Council. The council makes decisions on forestry and heritage sites, and is composed equally of appointees of the provincial government and the Haida Nation, with decisions made by consensus.

Another example is the (2016) Great Bear Rainforest Agreements between the seven First Nations in the Central Coast of British Columbia and the provincial government, which agreed to return $80 \%$ of the landscape to old-growth forest over a 250 -year timeframe and to support a conservation economy. While the legal mechanisms in colonial law for realizing these agreements are complex (Curran, 2017), the provincial government operationalized the forestry commitments through the Great Bear Rainforest (Forest Management) Act (2016), which establishes the annual allowable cut for the area, as agreed to pursuant to ecosystem-based management. Much of the landscape is designated in a new type of park, called conservancies, that permit the exercise of Aboriginal rights.

Finally, granting independent legal status and a voice to a river might make sense in unique areas where there are many overlapping claims and legal structures affecting a body of water, and where decision-making authority and priorities require clarity. An example is the Peace Athabasca Delta, a UNESCO World Heritage site and part of the larger Peace-Athabasca-MacKenzie River system. Flowing through three provinces, two territories, and dozens of treaty and non-treaty Indigenous traditional territories, it is affected by some of the largest industrial tar sands and hydroelectric projects in Canada. While colonial legal processes have failed to provide effective governance for one of the world's most important rivers (CBC/Radio Canada, 2017), perhaps an independent governance body for the river itself could force reparations.

\section{The Yarra River Protection (Wilip-gin Birrarung murron) Act, 2017 (vic), independent voices, indigenous rights and river rights}

\section{Katie O'Bryan}

\section{Monash University}

Historically, Victoria's water laws have not recognized Aboriginal people as having a role in managing and protecting Victoria's waterways. That changed with the enactment of the Yarra River Protection (Wilip-gin Birrarung murron) Act, 2017 (Vic). This act is significant because not only does it recognize a role for Aboriginal people in the management and protection of the Yarra, it is also said to give an 'independent voice' to the river (Premier of Victoria, 2017).

\section{The independent voice of the river and international developments}

Giving legal personhood to a natural object, with a voice (in the form of a guardian) to protect its interests, is an idea that has existed in theory since 1972, when Christopher Stone wrote his famous article, 'Should Trees Have Standing? Toward Legal Rights for Natural Objects'. With Stone's idea gaining momentum over the last few years, in 2017 
Aotearoa New Zealand became the first country to enact legislation giving legal personhood and an independent voice to a river (Finlayson, 2014). Shortly thereafter, several court rulings gave legal rights to rivers elsewhere, namely the Atrato River in Colombia (Bardeen, 2017) and the Ganges and Yamuna Rivers in India (O'Donnell \& Talbot-Jones, 2017b). And now Bangladesh has followed suit: in January 2019 the High Court of Bangladesh gave the status of 'legal person' to the Turag River (bdnews24.com, 2019).

But how do these developments compare with the Yarra River Protection Act, and what does it mean for the role of Indigenous people in river management?

\section{Key features of the Yarra River Protection (Wilip-gin Birrarung murron) Act}

The key features of relevance to Aboriginal Victorians in the Act include the following. First, the act treats the Yarra River as one living and integrated natural entity, an approach that reflects Aboriginal conceptions of the Yarra. Second, to reflect the Yarra as a single entity, the act provides for the development and implementation of an overarching strategic plan to guide the future use and development of the Yarra (Melbourne Water, n.d.).

While that plan is currently under development (Melbourne Water, n.d.), it will be informed by the Yarra protection principles. Statutory decision makers along the Yarra must have regard to these principles when performing their functions or exercising their powers in relation to the Yarra. Importantly, the principles highlight Aboriginal cultural values, heritage and knowledge, and the importance of involving traditional owners in policy planning and decision making.

The act also establishes the Birrarung Council, the 'independent voice for the river' (Minister of Planning, 2017). The council comprises 12 community and skill-based members, two of whom must be chosen by the Wurundjeri community, the traditional owners of much of the land through which the river flows. Significantly, the council is precluded from having any government representatives as members.

The council has two main roles. The first is to provide advice to the minister on the administration of the act. The second is to advocate for the protection and preservation of the Yarra. This role, along with the prohibition of government representation on the council, forms the basis for its depiction as the independent voice for the river.

\section{Comparing the Yarra River Protection Act 2017 and the Te Awa Tupua Act 2017}

So how does the New Zealand legislation differ from the Victorian legislation, given that both are said to give an independent voice to the river?

A major difference lies in the status of the river itself. Although the Yarra River Protection Act declares the Yarra one living and integrated natural entity, it does not give the Yarra independent legal standing, with all of the rights and liabilities that come with that status. The Birrarung Council, although able to advocate on behalf of the Yarra, is not its legal guardian and cannot initiate legal proceedings on its behalf. It is essentially an advisory body only. The Te Awa Tupua Act, on the other hand, specifically provides for the Whanganui River to have 'all the rights, powers, duties, and liabilities of a legal person', which are exercised on behalf of the river by Te Pou Tupua, the human face of the Whanganui River. This means that, unlike the Birrarung Council, Te Pou Tupua can initiate legal proceedings to protect the Whanganui River. 
Another distinction is that the river values to be protected in the Te Awa Tupua Act (called Tupua te Kawa) are intrinsically Māori-oriented in their conceptions of the river. In contrast, the river values to be protected in the Yarra River Protection Act, as reflected in the Yarra protection principles, are more wide-ranging, encompassing not just Aboriginal cultural values but also post-settlement cultural diversity and heritage, and values embodied in environmental, social, recreational, management and general protection principles.

Finally, the Birrarung Council was established to ensure that diverse community interests are involved in protecting and promoting the Yarra River, hence the need for it to have 12 members. Te Pou Tupua, with only two members (one nominated by the government and one by the iwi (Mãori tribes) with interests in the Whanganui River (Finlayson, 2017), was established to represent the Whanganui River, not community interests - that role is given to a different entity, Te Kōpuka, which has 17 members, including up to six Māori members.

\section{What does this mean for indigenous river management?}

The granting of independent legal status to the Whanganui River as part of the treaty settlement in the Te Awa Tupua Act does not give the Whanganui Iwi a direct say in the management of the Whanganui River. The members of Te Pou Tupua act on behalf of the river, not on behalf of their respective nominator. In that regard, it is not necessarily of benefit to the Māori. However, the river values to be upheld by Te Pou Tupua are intrinsically Māori in orientation, and other aspects of the settlement, such as Te Kōpuka, and the role of the Whanganui Iwi's post-settlement governance entity, do provide for Māori participation in the river's management.

The Yarra River Protection Act does not extend as far as the Te Awa Tupua Act in giving independent legal status to the Yarra. Nor does it create legal capacity in the Birrarung Council to seek redress in court for damage done to the Yarra. It does, however, give a direct, albeit advisory, voice to Aboriginal Victorians in the management of the Yarra. This signals a shift in the future of river management in Victoria towards one that is more inclusive of Aboriginal people. Accordingly, there are now calls for similar legislation in rivers west of Melbourne (Environmental Justice Australia, n.d.), and a Ministerial Advisory Committee has been established to engage communities and Aboriginal people to produce an action plan for the government to consider (Victoria State Government, n.d.).

That is not to say that the legal personhood model will not find favour elsewhere in Australia. The Aboriginal people of the Fitzroy River in the Kimberly region of Western Australia also are contemplating granting legal personhood to the Fitzroy River (Gleeson-White, 2018). And the local community of Margaret River, also in Western Australia, are seeking to provide legal rights for that river and appoint a local council as custodian (Lynch, 2018). So, it seems that the legal personhood concept is starting to gain some traction in Australia.

So how do the Victorian and New Zealand models compare with the court cases in India, Colombia and Bangladesh?

A clear difference among the approaches is the mode of recognition. In both the Victorian and New Zealand examples, recognition of an independent voice for the 
river arose through legislation, whereas in India, Colombia and Bangladesh, recognition of rivers as legal persons occurred by way of judicial determination.

Another difference is the nature of the voice given to the river. Where government representatives are appointed as guardians, there is the potential for a conflict of interest should economic imperatives clash with the river's rights. This has been addressed in the Whanganui River legislation because the guardian, although including a government representative, was established as an independent legal entity with a statutory obligation to act in the best interests of the river. And in the Victorian legislation, the Birrarung Council specifically prohibits the appointment of government representatives to avoid any conflict of interest in its provision of advice.

However, in the Ganga and Yamuna River court case, the High Court of Uttarakhand appointed senior public officials collectively to serve as the guardian of those rivers. Senior public officials already have numerous obligations, some of which are likely to conflict with these newly imposed responsibilities to look after the interests of these rivers. In addition, as the obligation was imposed by court order rather than initiated by the state, the state is required to source additional funding to enable the court-ordered guardians to fulfil their new tasks. Given this, as well as concerns about the legal implications of rivers causing harm through flooding and the interstate nature of the two rivers, it is not surprising that the High Court decision was stayed pending an appeal by the Indian Supreme Court (State of Uttarakhand \& Ors. v. Mohd. Salim \& Ors., 2017).

In contrast, the High Court of Bangladesh ordered the National River Protection Commission to be the guardian of the Turag River. Established in 2013 by the National River Protection Commission Act, its functions, however, are limited to making recommendations on the protection of Bangladesh's rivers. Accordingly, much like the Birrarung Council, it has only advisory authority and no powers of enforcement, a point that was acknowledged by the High Court (The Daily Star, 2019).

Finally, in Colombia, the Constitutional Court ordered the creation of a commission of guardians comprising representatives of both the government and the claimant communities. It also created an advisory group that includes the Humboldt Institute and the WWF Colombia, and an expert panel to monitor compliance with the court's orders (Vila, 2017).

\section{Conclusion}

The above brief discussion suggests that the independent voice of a river can take different forms depending on the circumstances in which it arose. Thus, what may work in one context may not work in another. In addition, it is important to consider how having an independent voice can affect Indigenous relationships with a river, something that did not feature in either the Indian or Bangladeshi cases. Finally, there are many other factors that can influence the implementation and recognition of a river's legal rights. The relative recency of these developments makes it difficult to judge how effective any of them will be. Accordingly, there are still many questions for which we do not yet have the answers. 


\section{Of rivers, deities and legal persons: a new approach to managing freshwater resources?}

\section{Gabriel Eckstein}

Texas A\&M University School of Law; International Water Resources Association; International Association for Water Law

Today, at least five rivers around the world - Whanganui in New Zealand (New Zealand, 2017), Yarra in Australia (Yarra River Protection (Wilip-gin Birrarung murron) Act, 2017), Atrato in Colombia (T-622/16, 2016), Narmada in India (Ghatwai, 2017; Times of India, 2017), and Vilcabamba in Ecuador (La Alianza Global por los Derechos de la Naturaleza, n.d.) - enjoy some measure of independent legal recognition under national law. Efforts to afford similar legal respect to the Ganges and Yamuna Rivers in India (LiveLaw News Network, 2017) and the Colorado River in the United States (Turkewitz, 2017) have also been made. The following is the last in a series of essays exploring this unique phenomenon. The purpose of the series was to engage in a dialogue and assess the merits and extent of such recognition, and to consider the possible ramifications for people and communities, and of course, the rivers protected under such actions. What emerged is an insightful and diverse conversation that offered critical and constructive analyses, and which furthered the conversation over this novel legal approach to the management of critical freshwater resources.

\section{Questions abound}

As a foundational issue, in her essay Erin O'Donnell asked the quite fundamental question of why a river might need to protect itself. In modern societies, people and communities have traditionally sought to protect natural resources through environmental laws and regulation, with varying results. Thus, it is unclear whether affording legal personality to rivers is intended to plug gaps that environmental regulations have failed to fill, is an evolutionary step in environmental protection, or possibly is some more fundamentally progressive approach to relating people with their surroundings. In any case, O'Donnell noted that affording a river a legal right to protect itself creates a paradox whereby the human obligation and burden to ensure that protection is lessened and possibly expunged.

Further scrutinizing such legal recognition, Ariella D'Andrea asserted in her essay that the diversity of mechanisms and components used to afford such legal recognition leaves much unclear in terms of the practicalities, implementation, efficacy and enforcement of these actions. Given the novelty of this approach for the management of rivers, D'Andrea raised a host of queries, ranging from whether the recognition applies to the river, its basin, or even the aquatic and surrounding biodiversity, to whether a river, recognized as a legal person (possibly like a corporation), can now be liable for taxes, harm from flooding, and ensuring its own water quality and quantity. In her essay, Julia Talbot-Jones further critiqued the phenomenon and questioned the mechanics of how the granting of legal personality to rivers could be operationalized. She also highlighted the reality that the new rights of these water bodies could only be protected through institutional mechanisms acting on their behalf, as well as adequate 
resources to support such responsibilities. As Talbot-Jones rightly suggested, legal rights without the means to protect them could simply become irrelevant.

The practicalities of implementation, however, are only some of the challenges facing the realization and appreciation of such action. Both Virginia Marshall and Deborah Curran in their essays pointed out that while some of these efforts are couched in terms of values ascribed to indigenous communities, the steps taken may not necessarily comport with those values. Both authors suggested that because of the unique relationship that indigenous communities enjoy with their natural surroundings, including rivers and other freshwater resources (Marshall focusing on Australia's Aboriginal Peoples, and Curran focusing on Canada's First Nations), indigenous peoples could actually find the notion of a river holding legal personality completely antithetical to their cultural beliefs and norms.

In a similar vein, it may be reasonable to question whether the approach and mechanisms used to instal legal personality for a river is actually based on the values of the local indigenous community or rather on a broader perspective that encompasses the ideals of both the Indigenous and the broader citizenry's perspective of sustainability and environmental protection. While the former could manifest in mechanisms that emphasize individual and communal stewardship, prioritizing of indigenous and environmental concerns, and the installation of decisional authority in the collective citizenry or an appointed public body, the latter could result in regulation-based restrictions, priorities for human health, and decision-making authority assigned to a governmental agency. Of course, the resulting mechanisms could also be a combination of both. However, whether a particular approach is appropriate for a distinct locale will likely have to be determined case by case, since conduct that is justified in one set of natural, cultural and political circumstances may not be supportable in a different scenario.

\section{Commonalities}

Despite the distinct differences in approach shown in the various examples explored in these essays, it is worth noting that in all of them, one of the chief motivations behind the decisions taken was the sincere desire to ensure the existence and sustainability of an invaluable freshwater resource. While some may debate the necessity of protecting a particular river or watershed, it seems reasonable to acknowledge that such a conservation justification is generally both rational and defensible. The resulting question that must be considered is whether the mechanisms used to achieve the particular objectives are appropriate and reasonable. Again, this can only be understood and undertaken on an ad hoc basis.

Nevertheless, altruistic environmental priorities are not the only or sole influences that have resulted in the recognitions of rivers as legal persons. In some instances, religious and cultural values may have helped inspire such outcomes. As Julia TalbotJones explained in her essay, in the case of the Whanganui River, the justification also included the desire to resolve long-standing ownership claims by the Māori indigenous community. In contrast, the decision by the High Court of the Indian state of Uttarakhand (Mohd. Salim v. State of Uttarakhand \& others, 2017) to recognize the Ganga and Yamuna Rivers as living entities, as well as the resolution adopted by the Madhya Pradesh state legislature recognizing the Narmada River as a living entity 
(Ghatwai, 2017; Times of India, 2017), appear to be grounded, at least partially, in the Hindu faith. While such objectives do not negate the sustainability rationale, in the case of the Whanganui River it injected an additional distinct element that provided a critical impetus for legal recognition of the river, but also complicated and lengthened the process, resulting in a quite unparalleled institutional and legal framework (New Zealand, 2017). In the case of the Ganga and Yamuna Rivers, the religious justification may have actually hastened the courts' ruling, although questions about implementing that judgment then led India's Supreme Court to stay that decision (Mandhani, 2017).

A further common factor that should be considered when examining the various examples is the assignment of guardianship or trusteeship for the river to a body whose responsibility is to represent the interests of the water body. Such an action is clearly based on the need to operationalize the legal standing criteria, which apply to all persons under law, whether human, corporate, or otherwise. However, as Katie O'Bryan indicated in her essay, there is a considerable range among the bodies discussed in the examples in terms of their structure and authority, and the resources allotted to support their responsibilities. Nevertheless, similar distinctions and disparities can be identified in terms of representational capacity for corporations, as well as children and the intellectually challenged, operating before the law. Accordingly, the institutional mechanism created to protect the interests of rivers that have been afforded individual legal recognition, and especially legal personality, should serve as a basis for further comparison and analyses.

\section{Conclusion}

Whether rights of personhood recognized in rivers will lead to cleaner and more bountiful water for people and the nature is still unknown. The judicial and legislative actions discussed in these essays are both novel and recent, and the complete range of outcomes, implications and repercussions have yet to be fully ascertained. One particular question not raised in this series is how this approach, in the face of a serious water deficiency, might balance the rights of people or a community to secure adequate supply of water against the sustainable needs of nature. Considering the recent debilitating crisis in Cape Town, South Africa, and ongoing parched conditions in Afghanistan, Australia, Bolivia, Iran, Jordan, Mongolia, Morocco, Uruguay, western Canada and other parts of the world, it may be that recognizing individual rights in rivers may not be appropriate in all corners of the globe.

Nevertheless, the steps taken in Australia, Colombia, India and New Zealand have not gone unnoticed. Efforts to duplicate these decisions and outcomes have been explored in Chile (Benöhr \& Lynch, 2018), Nigeria (Breyer, 2018), the United States (Benson, 2017) and other countries. Moreover, they have become fodder for multiple legal and policy analyses, which are critically necessary to explore the viability and practicalities of such efforts.

This series of essays on legislative and judicial actions taken to recognize some measure of independent legal personality for rivers under national law was undertaken precisely with the objective of furthering the assessment and discussion of this distinct new approach to the management of the world's critical freshwater resources. With this in mind, we welcome further commentary, analyses and opinions in response to these essays. 


\section{Disclosure statement}

No potential conflict of interest was reported by the authors.

\section{ORCID}

Gabriel Eckstein (D) http://orcid.org/0000-0002-9393-2362

Virginia Marshall (D) http://orcid.org/0000-0003-4487-4730

Erin O’Donnell (D) http://orcid.org/0000-0002-2615-8012

Julia Talbot-Jones (D) http://orcid.org/0000-0002-8425-1792

Deborah Curran (D) http://orcid.org/0000-0002-6014-0553

Katie O’Bryan (D) http://orcid.org/0000-0003-3203-7839

\section{References}

\section{Cases}

Haida Nation v. British Columbia (Minister of Forests) (2004, November 18). [2004] 3 S.C.R. 511, 2004 SCC 73. Supreme Court of Canada. Retrieved from https://scc-csc.lexum.com/scccsc/scc-csc/en/item/2189/index.do

Lalit Miglani v. State of Uttarakhand \& others (2017, March 30). Writ Petition (PIL) No.140 of 2015. High Court of Uttarakhand at Nainital. Retrieved from http://www.indiancourts.nic.in/ ddir/uhc/RS/judgement/31-03-2017/RS30032017WPPIL1402015.pdf

Mabo v. Queensland (No 2) (1992, June 3). [1992] HCA 23, (1992) 175 CLR 1. High Court of Australia. Retrieved from http://www.austlii.edu.au/cgi-bin/viewdoc/au/cases/cth/HCA/1992/ 23.html

Mohd. Salim v. State of Uttarakhand \& others (2017, March 20). Writ Petition (PIL) No.126 of 2014. High Court of Uttarakhand at Nainital. Retrieved from http://www.indiancourts.nic.in/ ddir/uhc/RS/orders/22-03-2017/RS20032017WPPIL1262014.pdf

R. E. Sparrow v. The National Indian Brotherhood/Assembly of First Nations et al. (1990, May 31). [1990] 1 S.C.R. 1075. Supreme Court of Canada. Retrieved from https://scc-csc.lexum. com/scc-csc/scc-csc/en/item/609/index.do

R. F. Wheeler \& E.G. Huddle v. Attorney General of the State of Jola, Dr. P. Carrion (2011, March 30). Judgement No. 11121-2011-0010. Provincial Court of Justice of Loja. Retrieved from https://mariomelo.files.wordpress.com/2011/04/proteccion-derechosnatura-loja-11.pdf

R. v. Van der Peet v. The Attorney General of Quebec et al. (1996, August 21). [1996] 2 S.C.R. 507. Supreme Court of Canada. Retrieved from https://scc-csc.lexum.com/scc-csc/scc-csc/en/ item/1407/index.do

Shriomani Gurudwara Prabandhak v. Shri Som Nath Dass \& Ors. (2000, March 29). Supreme Court of Indi. Retrieved from https://indiankanoon.org/doc/1478973/

Sierra Club v. Morton (1972). U.S. Supreme Court, 405: 727. Retrieved from https://supreme. justia.com/cases/federal/us/405/727/

State of Uttarakhand \& Ors. v. Mohd. Salim \& Ors. (2017, July 7). Supreme Court of India. Retrieved from https://www.sci.gov.in/supremecourt/2017/18199/18199_2017_Order_07-Jul2017.pdf

T-622/16 (2016). Corte Constitucional, Republica de Colombia, Sala Sexta de Revisión. Retrieved from http://cr00.epimg.net/descargables/2017/05/02/14037e7b5712106cd88b687525dfeb4b.pdf

The Colorado River Ecosystem/Deep Green Resistance et al. v. State of Colorado (2017, September 26). U.S. District Court for the District of Colorado. Retrieved from https://www. courthousenews.com/wp-content/uploads/2017/09/Colorado-River.pdf

Yogendra Nath Naskar v. Commission of Income-Tax (1969, February 18). 1969 AIR 1089, 1969 SCR (3) 742. Supreme Court of India. Retrieved from https://indiankanoon.org/doc/1874024/ 


\section{Laws, statutes, and governmental programmes}

Bolivia (2010, December 21). Law of the rights of mother earth, Law No. 071. Retrieved from http://ilo.org/dyn/natlex/docs/ELECTRONIC/92470/107736/F1549363084/BOL92470.pdf

Bolivia (2012, October 15). Ley marco de la madre tierra y desarrollo integral para vivir bien, Law No. 300. Retrieved from http://ilo.org/dyn/natlex/docs/ELECTRONIC/92468/107732/F1782935448/BOL92468.pdf

Carrier Sekani Tribal Council (n.d.). Yinke Dene 'Uza'hne' Guide to surface water quality standards. Retrieved from http://www.carriersekani.ca/news/yinke-dene-uzahne-guide-to-sur face-water-quality-standards

City of Pittsburgh Code of Ordinances (2019). Chapter 618: Marcellus shale natural gas drilling, title six, conduct, article 1 regulated rights and actions, supplement 33 update 4 . Retrieved from https://library.municode.com/pa/pittsburgh/codes/code_of_ordinances?nodeId=COOR_ TITSIXCO_ARTIRERIAC_CH618MASHNAGADR

Constitution of the Republic of Ecuador (2008). Retrieved from http://pdba.georgetown.edu/ Constitutions/Ecuador/english08.html

Council of Australian Governments (2004). Australia National Water Initiative. Retrieved from http://www.agriculture.gov.au/water/policy/nwi

Ecuador (2014, August 5). Ley de recursos hídricos usos y aprovechamiento del agua, Of. No. SAN-2014-1178. Retrieved from http://extwprlegs1.fao.org/docs/pdf/ecu165480.pdf

Great Bear Rainforest Agreements (2016). Retrieved from https://greatbearrainforest.gov.bc.ca/ tile/gbr-agreement-highlights/

Great Bear Rainforest (Forest Management) Act (2016). Retrieved from http://www.bclaws.ca/ civix/document/id/lc/statreg/16016

Kunst'aa guu - Kunst'aayaa Reconciliation Protocol (2009). Retrieved from http://www.haidana tion.ca/wp-content/uploads/2017/03/Kunstaa-guu_Kunstaayah_Agreement.pdf

Minister of Planning (2017). Landmark legislation to protect the Yarra River. Premier of Victoria website. 22 June 2017. Retrieved from https://www.premier.vic.gov.au/landmark-legislationto-protect-the-yarra-river/

New Zealand (2014, July 27). Te Urewera Act 2014, Public Act 2014 No 51. Retrieved from http://www.legislation.govt.nz/act/public/2014/0051/latest/whole.html

New Zealand (2017). Te Awa Tupua [Whanganui River Claims Settlement] Act 2017, Public Act, 2017 No 7. Retrieved from http://www.legislation.govt.nz/act/public/2017/0007/latest/whole. html

Okanagan Nation Alliance (n.d.). Syilx water declaration. Retrieved from https://www.syilx.org/ about-us/syilx-nation/water-declaration/

Premier of Victoria (2017, February 26). Protecting the Yarra River for generations to come. Premier of Victoria website. Retrieved from https://www.premier.vic.gov.au/protecting-theyarra-river-for-generations-to-come/

Stk'emlúpsemc te Secwépemc Nation (2017). Honouring our sacred connection to Pípsell. Retrieved from https://stkemlups.ca/files/2013/11/2017-03-ssnajaxdecisionsummary_0.pdf

Tsleil-Waututh Nation (2015). Assessment of the trans mountain pipeline and tanker expansion proposal. Retrieved from https://twnsacredtrust.ca/assessment-report-download/

Tsleil-Waututh Nation (n.d.). Burrard Inlet Action Plan. Retrieved from https://twnsacredtrust. ca/burrard-inlet-action-plan/

Waitangi Tribunal Report 1999 (1999). Chapter 6: How the river was taken, in The Whanganui river report. GP Publications. Retrieved from https://forms.justice.govt.nz/search/Documents/ WT/wt_DOC_68450539/Whanganui\%20River\%20Report\%201999.pdf

Yarra River Protection (Wilip-gin Birrarung murron) Act (2017) No. 49 of 2017. Retrieved from http://www.legislation.vic.gov.au/Domino/Web_Notes/LDMS/PubStatbook.nsf/ 51dea49770555ea6ca256da4001b90cd/DD1ED871D7DF8661CA2581A700103BF0/\$FILE/17049aa\%20authorised.pdf 


\section{Books, articles, and monographs}

Asch, J., Broadhead, K., Lloyd-Smith, G., \& Owen, S. (2018). Secwepemc: Lands and resource Law research project. Retrieved from https://www.uvic.ca/law/assets/docs/ilru/SNTC\%20Law \%20Book\%20July\%202018.pdf

Australian Earth Laws Alliance. (n.d.). Exploring the legal status of nature. Retrieved from https://www.earthlaws.org.au/events/exploring-the-legal-status-of-nature/

Australian Panel of Experts on Environmental law. (2017). Blueprint for the next generation of Australian Environmental Law. Melbourne, Australia: APEEL.

Bardeen, S. (2017, May 11). Colombian river gains legal rights. InternationalRivers.org. Retrieved from https://www.internationalrivers.org/blogs/433/colombian-river-gains-legal-rights

BBC News Service (2017, July 7). India's Ganges and Yamuna rivers are 'not living entities'. BBC News. Retrieved from https://www.bbc.com/news/world-asia-india-40537701

bdnews24.com. (2019, January 30). Bangladesh court gives Turag, other rivers status of 'legal person' to save them from encroachment. Retrieved from https://bdnews24.com/bangladesh/ 2019/01/30/bangladesh-court-gives-turag-other-rivers-status-of-legal-person-to-save-them from-encroachment

Benöhr, J., \& Lynch, P. (2018, August 14). Should rivers have rights? A growing movement says it's about time. YaleEnvironment360. Retrieved from https://e360.yale.edu/features/shouldrivers-have-rights-a-growing-movement-says-its-about-time

Benson, R. D. (2017, December 15). Is there a right to life for the Colorado River? Denver Post. Retrieved from https://www.denverpost.com/2017/12/15/is-there-a-right-to-life-for-the-color ado-river/

Boyd, D. R. (2012). The right to a healthy environment: Revitalizing Canada's constitution. Vancouver: UBC Press.

Breyer, M. (2018, March 12). River Ethiope could be first waterway in Africa recognized as a living entity. treehugger.com. Retrieved from https://www.treehugger.com/conservation/riverethiope-could-become-first-waterway-africa-recognized-living-entity.html

Burdon, P. (2010). The rights of nature: Reconsidered. Australian Humanities Review, 49, 69-89. Retrieved from https://therightsofnature.org/wp-content/uploads/pdfs/TheRightsofNatureReconsidered.pdf

CBC/Radio Canada. (2017). In danger: UNESCO issues warning about wood Buffalo National Park. Retrieved from https://www.cbc.ca/news/canada/edmonton/unesco-wood-buffalonational-park-in-danger-conservation-fears-1.4019549

Chandran, R. (2017, March 21). India's sacred Ganges and Yamuna rivers granted same legal rights as humans. Reuters. Retrieved from https://www.reuters.com/article/us-india-water-law making-idUSKBN16S109

Croley, S. P. (1998). Theories of regulation: Incorporating the administrative process. Columbia Law Review, 98, 1-168. Retrieved from http://www.sjamsiarfiaub.lecture.ub.ac.id/files/2012/02/ buku-regulati-administrasi-publik.pdf

Curran, D. (2017). 'Legalizing' the great bear rainforest: Colonial adaptations towards conservation and reconciliation. McGill Law Journal, 62(3), 813-860. Retrieved from https://dspace. library.uvic.ca/handle/1828/9181

Daly, E. (2012, April). The ecuadorian exemplar: The first ever vindications of constitutional rights of nature. Review of European Community \& International Environmental Law, 21(1), 63-66. Retrieved from https://onlinelibrary.wiley.com/doi/abs/10.1111/j.1467-9388.2012.00744.x

Environmental Justice Australia. (n.d.). Rivers of the west. Retrieved from http://www.envirojus tice.org.au/projects/rivers-of-the-west/

Finlayson, C. (2014, August 6). Whanganui river deed of settlement signed. New Zealand Government website. Retrieved from https://www.beehive.govt.nz/release/whanganui-riverdeed-settlement-signed

Finlayson, C. (2017, September 4). First Te Pou Tupua appointed. New Zealand Government website. Retrieved from https://www.beehive.govt.nz/release/first-te-pou-tupua-appointed 
Ghatwai, M. (2017, May 4). Madhya Pradesh Assembly declares Narmada living entity. Indian Express. Retrieved from https://indianexpress.com/article/india/madhya-pradesh-assemblydeclares-narmada-living-entity-4639713/

Gleeson-White, J. (2018, March 31). It's only natural: The push to give rivers, mountains and forests legal rights. The Guardian. Retrieved from https:/www.theguardian.com/australia-news/2018/ apr/01/its-only-natural-the-push-to-give-rivers-mountains-and-forests-legal-rights

Javorsky, N. (2019, March 1). Why Toledo Just Gave Legal Rights to Lake Erie. Citylab. Retrieved from https://www.citylab.com/environment/2019/03/lake-erie-bill-of-rights-toledo-votersgreat-lakes-pollution/583738/

Kauffman, C. M., \& Martin, P. L. (2017, April). Can rights of nature make development more sustainable? Why some ecuadorian lawsuits succeed and others fail. World Development, 92, 130-142. Retrieved from https://www.sciencedirect.com/science/article/abs/pii/ S0305750X16305496\#!

La Alianza Global por los Derechos de la Naturaleza (n.d.). Celebran el Primer Caso Exitoso de Exigibilidad de los Derechos de la Naturaleza en Ecuador. Retrieved from https://therightsof nature.org/celebran-el-primer-caso-exitoso-de-exigibilidad-de-los-derechos-de-la-naturalezaen-ecuador/

LiveLaw News Network (2017, March). A first in India: Uttarakhand HC declares Ganga, Yamuna Rivers as living legal entities [Read judgment]. Retrieved from https://www.livelaw. in/first-india-uttarakhand-hc-declares-ganga-yamuna-rivers-living-legal-entities/

Lynch, J. (2018, March 22). Calls to give legal rights to nature flow to WA's South West. $A B C$ South West WA website. Retrieved from https://www.abc.net.au/news/2018-03-23/call-to-givemargaret-river-same-legal-rights-as-humans/9578090

Mandhani, A. (2017, July 8). SC stays Uttarakhand HC's order declaring Ganga and Yamuna Rivers as living legal entities [Read order]. LiveLaw.in. Retrieved from https://www.livelaw.in/sc-staysuttarakhand-hcs-order-declaring-ganga-yamuna-rivers-living-legal-entities-read-order/

Marshall, V. (2017). Overturning aqua nullius: Securing aboriginal water rights. Canberra: ANU Press. Retrieved from https://aiatsis.gov.au/publications/products/overturning-aqua-nulliussecuring-aboriginal-water-rights/paperback

Melbourne Water (n.d.). Developing the Yarra Strategic plan. Retrieved from https://www. melbournewater.com.au/about-us/our-customers/developing-yarra-strategic-plan

Morgan, B., \& Yeung, K. (2007). An introduction to law and regulation: Text and materials. Cambridge, UK: Cambridge University Press.

Mount, N. (2017, October 6). Can a river have legal rights? I visited the jungles of Colombia to find out. The Conversation. Retrieved from https://theconversation.com/can-a-river-havelegal-rights-i-visited-the-jungles-of-colombia-to-find-out-84878

Naffine, N. (2009). Law's meaning of life: Philosophy, religion, darwin and the legal person. Oxford, UK: Hart Publishing.

Napoleon, V., \& Overstall, R. (2007, February). Indigenous laws: Some issues, considerations and experiences. An opinion paper prepared for the Centre for Indigenous Environmental Resources (CIER). Retrieved from http://caid.ca/LawIndIss2007.pdf

O’Donnell, E. (2017). Competition or collaboration? Using legal persons to manage water for the environment in Australia and the United States. Environmental and Planning Law Journal, 34, 503-521.

O'Donnell, E. (2018). Legal rights for rivers: competition, collaboration and water governance. London: Routledge.

O’Donnell, E., \& MacPherson, E. (2018). Voice, power and legitimacy: The role of the legal person in river management in New Zealand, Chile and Australia. Australasian Journal of Water Resources. Retrieved from https://www.tandfonline.com/doi/full/10.1080/13241583. 2018.1552545?af=R

O'Donnell, E., \& Talbot-Jones, J. (2017a). Legal rights for rivers: What does this actually mean? Australian Environment Review, 32, 159-162.

O'Donnell, E., \& Talbot-Jones, J. (2017b). Three rivers are now legally people: But that's just the start of looking after them. The Conversation. 23 March 2017. Retrieved from https://thecon 
versation.com/three-rivers-are-now-legally-people-but-thats-just-the-start-of-looking-afterthem-74983

O'Donnell, E., \& Talbot-Jones, J. (2018). Creating legal rights for rivers: Lessons from Australia, New Zealand, and India. Ecology and Society, 23, 7. Retrieved from https://www.ecologyandso ciety.org/vol23/iss1/art7/

Radio New Zealand (2017, March 16). What it means to give the Whanganui River the same rights as a person. RNZ.com. Retrieved from https:/www.rnz.co.nz/news/the-wireless/374515/ what-it-means-to-give-the-whanganui-river-the-same-rights-as-a-person

Revkin, A. (2008, September 29). Ecuador constitution grants rights to nature. New York Times Blog. Retrieved from https://dotearth.blogs.nytimes.com/2008/09/29/ecuador-constitutiongrants-nature-rights/

Roy, E. A. (2017, March 16). New Zealand river granted same legal rights as human being. The Guardian. Retrieved from https://www.theguardian.com/world/2017/mar/16/new-zealandriver-granted-same-legal-rights-as-human-being

Salmond, A. (2014, Winter). Tears of rangi: water, power, and people in New Zealand. HAU: Journal of Ethnographic Theory, 4(3), 285-309. Retrieved from https://www.journals.uchicago. edu/doi/full/10.14318/hau4.3.017

Stone, C. (1972). Should trees have standing? Toward legal rights for natural objects. Southern California Law Review, 45, 45-501. Retrieved from https://iseethics.files.wordpress.com/2013/ 02/stone-christopher-d-should-trees-have-standing.pdf

Sunstein, C. R. (1990). After the rights revolution: Reconceiving the regulatory state. Cambridge, MA: Harvard University Press.

The Daily Star (2019, January 31). River, rights commissions seem to be dummy bodies: HC. Retrieved from https://www.thedailystar.net/country/national-river-human-rights-commis sions-seem-be-dummy-commissions-1695496

Times of India (2017, May 4). Narmada declared a 'living entity'. Times of India. Retrieved from https:/timesofindia.indiatimes.com/city/bhopal/narmada-declared-a-living-entity/article show/58504665.cms

Turkewitz, J. (2017, September 26). Corporations have rights. Why shouldn't rivers? New York Times. Retrieved from https://www.nytimes.com/2017/09/26/us/does-the-colorado-river-haverights-a-lawsuit-seeks-to-declare-it-a-person.html

Victoria State Government. (n.d.). Water and planning ministers announce the waterways of the west. Retrieved from https://www.water.vic.gov.au/media-releases/2018/waterways-of-the-west

Vila, L. (2017, May 17). The importance of the Atrato River in Colombia gaining legal rights. Earth Law Center website. Retrieved from https://www.earthlawcenter.org/blog-entries/2017/ 5/the-importance-of-the-atrato-river-in-colombia-gaining-legal-rights

Walker, C. (2014, July 12). Lake Winnipeg should be 'recognized as a person,' says advocate. CBC News. Retrieved from https://www.cbc.ca/news/indigenous/lake-winnipeg-should-be-recog nized-as-a-person-says-advocate- 1.2703350

Walker, C. (2017, December 4). Attorney to withdraw Colorado River Lawsuit under threat of sanctions. Westword. Retrieved from https://www.westword.com/news/colorado-river-lawsuitto-be-withdrawn-due-to-potential-sanctions-9746311

Williams, T. (2019, February 17). Legal rights for lake erie? Voters in Ohio City will decide. New York Times. Retrieved from https://www.nytimes.com/2019/02/17/us/lake-erie-legal-rights. html

World People's Conference on Climate Change and the Rights of Mother Earth (2010). Proposal universal declaration on the rights of mother earth. Retrieved from https://pwccc.wordpress. com/programa/ 